\title{
Prevalence of non-infectious claw disorders in Egyptian dairy farms in relation to the flooring system
}

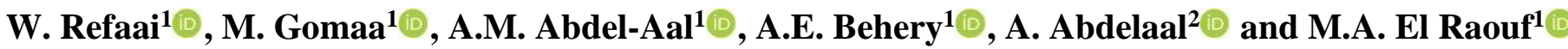 \\ ${ }^{1}$ Department of Surgery, Anesthesiology, and Radiology, ${ }^{2}$ Department of Internal Medicine, Faculty of Veterinary Medicine, \\ Zagazig University, Zagazig, Egypt
}

\begin{tabular}{l} 
Article information \\
\hline Article history: \\
Received April 15, 2021 \\
Accepted June 12, 2021 \\
Available online December 19, 2021
\end{tabular}

\section{Keywords:}

Non-infectious claw disorders

Flooring system

Earthen floor

Desert floor

Dairy cows

\section{Correspondence:}

M.A. El Raouf

dr_mustafa13@yahoo.com

\begin{abstract}
Lameness is one of the most prevalent and costly maladies affecting dairy cattle. It has been ranked as the third after mastitis and reproductive failure. One of the leading causes of lameness is corium tissue damage and hence claw horn lesions development. Flooring system was found to have an impact on the development of such lesions. Therefore, the objective of the present study was to study the effect of flooring system on the development of four non-infectious claw disorders in Egyptian dairy farms. Another objective was to study the effect of claw disorders on reproductive performance and total milk production. Four dairy herds with earthen floor $(n=2)$ and desert floor $(n=2)$ from Ash-Sharkia and Ismailia Provinces were included in this study. Results revealed that the prevalence of white line disease (WLD) was the highest among recorded lesions in earthen floor farms $2.7 \%$ followed by sole ulcer (SU) $2.1 \%$ and sole abscess (SA) $1.7 \%$ then vertical wall fissures (VWF) $1.6 \%$. While in the desert floor farms, VWF and SA were reported in $0.8 \%$ of animals followed by WLD and SU in $0.4 \%$ and $0.3 \%$ of animals, respectively. The noninfectious claw disorders were detected mainly in hindlimbs in earthen floor farms when compared to forelimbs $6.6 \%$ and $1.5 \%$, respectively while in the desert floor farms were nearly equal for the forelimbs $1.1 \%$ and hindlimbs $1.2 \%$. In conclusion, the animals housed in earthen floor farms were more susceptible to non-infectious claw disorders than those housed in desert floor.
\end{abstract}

DOI: $10.33899 /$ ijvs.2021.129754.1685, (CAuthors, 2022, College of Veterinary Medicine, University of Mosul.

This is an open access article under the CC BY 4.0 license (http://creativecommons.org/licenses/by/4.0/).

\section{Introduction}

Lameness in cattle is one of the serious problems in dairy industry and represents the third in importance after mastitis and infertility $(1,2)$. Approximately $90 \%$ of cases with lameness are due to claw disorders (3). During the past decades, in response to the demand of high milk productivity, intensive husbandry with free stall yards were implemented with high risks of claw diseases (4). About one third of Spanish dairy cows, 36\% of the United Kingdom cows and $70 \%$ of Dutch cows have been reported with at least one claw disorder (5-7). Claw disorders can be classified into infectious (such as interdigital dermatitis and digital dermatitis) and noninfectious disorders (such as
Vertical wall fissure (VWF), White line disease (WLD), Sole ulcer (SU), Sole abscess (SA)) and each disorder has a specific effect on the performance of dairy cows $(8,9)$.

Claw disorders affect the animal welfare and health that is the important issue in dairy herd production. In addition, they cause high economic complications due to reduced productivity, increased early culling risks, reduced fertility rates and costs of treatment $(10,11)$. Several factors affect claw health and risk of claw lesions including environmental factors such as facilities designing and management practices and genetics (10,12-14). The environment has a great influence on the incidence of claw disorders and lameness in dairy herds. The flooring of the dairy farms has been shown to have a significant role in 
claw health $(15,16)$. Reduction in prevalence of claw disorders in cows housed in soft surface floors than those housed in concrete floors was previously reported (17).

In order to decrease the incidence of the claw disorders in dairy herds, more attention should be paid to the flooring system. The urgency of research about the suitable flooring is increased. Therefore, the objective of the present study was to study the effect of flooring system on the development of four non-infectious claw disorders in Egyptian dairy farms. In addition, to study the effect of claw disorders on reproductive performance and total milk production in one earthen dairy farm where farm records were available.

\section{Materials and methods}

\section{Animals}

In this study, two earthen (937 dairy cows) and two desert (901 dairy cows) Egyptian dairy farms in Sharkia and Ismailia provinces were included. In all farms, concrete floor was established around feed bunks and water troughs. Total mixed ration was supplied with free water access. Cows were milked three times daily in a milking parlor. Pregnant lactating cows were dried at the end of $7^{\text {th }}$ month of pregnancy.

\section{Data collection}

Lame cows were primarily collected from earthen and desert farms according to the farm records, herdsmen, claw trimmers and in addition to looking in yards and during walking to the milking parlor and subjected for further examination by our team during a total period of one year. Suspected cases were examined for lameness at standing and during walking on a leveled floor using a 5-point lameness scoring system (18). The locomotion scoring and assessment methods were previously described (11). Where, cows had lameness score 2-5 were further examined and the affected limb/limbs were identified. In this study, four non-infectious claw disorders were included (VWF, WLD, SU, SA) (Figure 1).

To study the effect of non-infectious claw disorders on reproductive performance and total milk production, data about calving interval, days open, No. services/conception, and total milk produced by both affected and healthy cows were collected from farm records. In an individual recording sheet, type of claw lesion, lameness score, affected limb/s, site of lesion, reproductive parameters (calving interval, days open, No. of services/conception, and lactation season) were written down.

\section{Statistical analysis}

The prevalence of non-infectious claw disorders was compared between earthen and desert floor farms using Chi Square test. The difference in calving interval, days open, number of service per conception and 305-day lactation milk yield between cows that were diagnosed with healthy feet and those identified with non-infectious claw disorders (data from earthen floor farm only) was examined using Wilcoxon rank sum test. The statistical analysis was performed using the SPSS statistical software version 17 (IBM, USA). The critical P-value was set at 0.05 for all analyses.
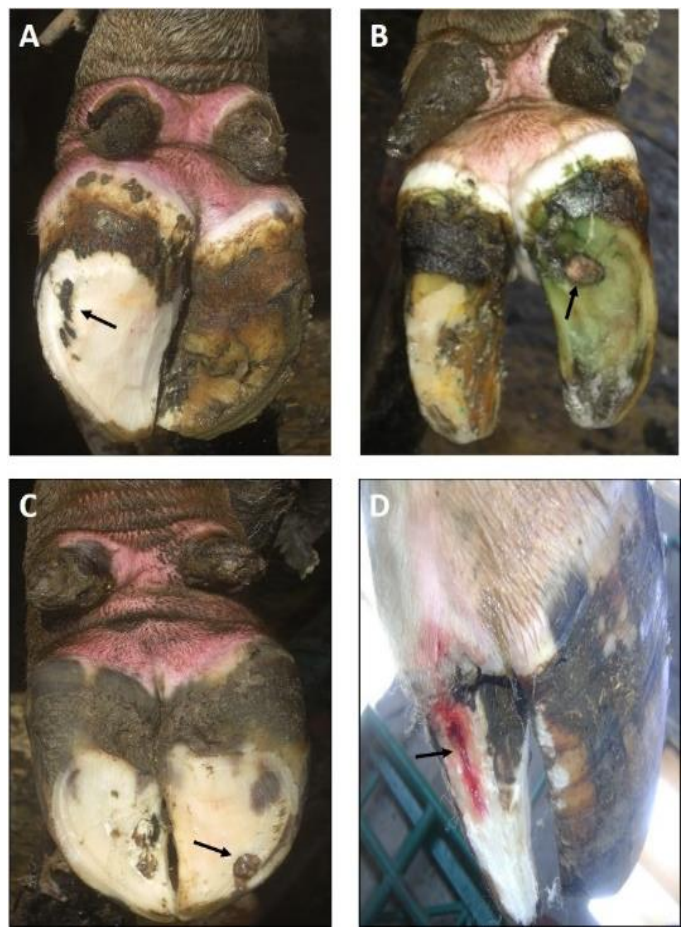

Figure 1: Different non-infectious claw disorders in cattle. A) WLD at the left lateral claw of the hindlimb (arrow). B) $\mathrm{SU}$ at the right lateral claw of the hindlimb (arrow). C) SA at the right lateral claw of the hindlimb (arrow). D) VWF of the left medial claw of the hindlimb (arrow).

\section{Results}

\section{Prevalence of non-infectious claw disorders}

The prevalence of non-infectious claw disorders was higher in earthen than desert floor farms with the percentages of $8.1 \%$ and $2.3 \%$, respectively. The prevalence of WLD was the highest among recorded lesions in earthen floor farms with the percentages of $2.7 \%$ followed by SU with the percentages of $2.1 \%$ and SA with the percentages of $1.7 \%$ then VWF with the percentages of $1.6 \%$. While in the desert floor farms, WF and SA were recorded in $0.8 \%$ of animals followed by WLD and SU were recorded in $0.4 \%$ and $0.3 \%$ of animals, respectively. Non-infectious claw disorders were detected mainly in hindlimbs in earthen floor farms when compared to forelimbs $(6.6 \%$ and $1.5 \%)$. While in desert floor farms, the affections were nearly equal in both limbs with the percentages of $1.1 \%$ in forelimbs and $1.2 \%$ in hindlimbs (Table 1). 


\section{Effect of non-infectious claw disorders on reproductive performance and total milk production}

The calving interval and days open were significantly increased in the affected cows than the normal ones. The number of services/conception was nearly similar in both affected and normal cows. The total amount of milk produced per cow for the season was significantly decreased in the affected cows than the normal ones (Table 2).

Table 1: Prevalence of non-infectious claw disorders in Egyptian dairy farms in relation to flooring system

\begin{tabular}{|c|c|c|c|c|c|c|c|}
\hline \multirow{2}{*}{ Item } & \multicolumn{3}{|c|}{ Earthen floor farms ( $\mathrm{n}=937$ cows) } & \multicolumn{3}{|c|}{ Desert floor farms ( $\mathrm{n}=901$ cows $)$} & \multirow{2}{*}{$\begin{array}{c}\text { Overall prevalence } \\
(\mathrm{n}=1838 \text { cows })\end{array}$} \\
\hline & Forelimb & Hindlimb & Total N (\%) & Forelimb & Hindlimb & Total N(\%) & \\
\hline WLD & 4 & 21 & $25(2.7 \%)$ & 2 & 2 & $4(0.4 \%)$ & $29(1.6 \%)$ \\
\hline SU & 1 & 19 & $20(2.1 \%)$ & 1 & 2 & $3(0.3 \%)$ & $23(1.3 \%)$ \\
\hline SA & 3 & 13 & $16(1.7 \%)$ & 4 & 3 & $7(0.8 \%)$ & $23(1.3 \%)$ \\
\hline VWF & 6 & 9 & $15(1.6 \%)$ & 3 & 4 & $7(0.8 \%)$ & $22(1.2 \%)$ \\
\hline Total & $14(1.5 \%)$ & $62^{* *}(6.6 \%)$ & $76(8.1 \%)$ & $10(1.1 \%)$ & $11(1.2 \%)$ & $21^{*}(2.3 \%)$ & $97(5.3 \%)$ \\
\hline
\end{tabular}

* Significance between earthen and desert floor farms, $\mathrm{P}<0.05$. ** Significance between forelimb and hindlimb of earthen floor farms, $\mathrm{P}<0.05$.

Table 2: Reproductive performance of both healthy and non-infectious claw disorders-affected dairy cows in earthen farm

\begin{tabular}{lcc}
\hline \multirow{2}{*}{ Item } & \multicolumn{2}{c}{ Mean \pm SEM } \\
\cline { 2 - 3 } & Normal cows No. 277 & Lame cows No. 67 \\
\hline Calving interval (Days) & $313 \pm 17$ & $450 \pm 18^{*}$ \\
Days Open (Days) & $157 \pm 8$ & $281 \pm 27^{*}$ \\
No. of services / conception & $2.2 \pm 0.1$ & $2.6 \pm 0.2$ \\
Total milk produced (Kg/cow/season) & $8876 \pm 322$ & $7917 \pm 290^{*}$ \\
\hline
\end{tabular}

* Significance between groups, $\mathrm{P}<0.05$.

\section{Discussion}

Lameness is an important issue in dairy farms causing severe pain and leading to much economic losses for producers $(1,11,19)$. About $90 \%$ of lameness incidence is due to claw lesions (20). The housing environment is obviously to have large impact in occurrence of claw lameness among dairy herds and the floor system is hypothesized as important and main factor in locomotion and claw heath (21).

In the present study, it was noticeable that the noninfectious claw disorders included in this study were more prevalent in earthen than desert floor farms, $8.1 \%$ and $2.3 \%$, respectively. This might be due to the ability of the desert floors to maintain dryness for longer periods especially during winter season that give more comfort to the animals and maintain the health of the claws (21). Moreover, keeping the dairy cows on pasture is associated with decrease in risks of lameness $(22,23)$. In contrast, a study by (24) showed increased risks of WLD, SU and digital dermatitis in grazing farms for $24 \mathrm{~h}$ per day in comparison with housing farms for $24 \mathrm{~h}$ per day.

The earthen floors when compared to desert ones has the disadvantage of accumulating manure with high moisture content for a longer period with direct contact to cow claws. This has a detrimental effect on the claw horn and remains a challenge in achieving satisfactory hygienic measures in the dairy farms (25).

In the present study, the hind limbs were affected more than the fore limbs in both types of dairy farms (3,26-29). This was attributed to the higher weight bearing on hind limbs due to overweight of udder in heavy milking cows and during late pregnancy (30). In addition, hind limbs are in direct contact with urine and manure than fore limbs which weakens claw horn and lower its resistance with the resultant claw lesions. WLD was the mostly recorded claw disorder among dairy cows in the earthen and desert floor farms followed by SU and SA then VWF.

Cattle lameness leads to major losses in the dairy herds. Reduction in milk production is one of the major losses in dairy farms that may be estimate around $25-35 \%$ (24,31). In addition, lowering the cow fertility by increasing days open and calving intervals as well as conception rate is considered major risk in dairy cows culling (32). Another factor of losses is the costs of lameness treatment and increased labor number and time of work (33). We investigated in the present study the effect of lameness caused by non-infectious claw disorders on the animals' reproductive performance and milk productivity. We found that the milk production was reduced by $9.6 \%$ in affected cows and so the fertility was decreased significantly (increasing calving intervals and days open) as previously recorded $(2,8)$. 


\section{Conclusion}

WLD, SU, SA and VWF were more commonly occurred in earthen than desert floor farms. Milk production and reproductivity were significantly reduced in the affected cows. Further work is still required to apply such study on a large scale of dairy farms all over Egypt. Finally, we advise the owners and livestock managers to design their farms in the desert areas in order to decrease the incidence of noninfectious claw disorders and reduce their hazards on dairy productions.

\section{Acknowledgement}

The authors would like to thank the farm managers for their support and providing all facilities for this work. The authors did not get fund for this work.

\section{Conflict of interest}

The authors declare that they have not conflict of interest.

\section{References}

1. Bruijnis MRN, Hogeveen H, Stassen EN. Measures to improve dairy cow foot health: Consequences for farmer income and dairy cow welfare. Animal. 2013;7(1):167-175. DOI: 10.1017/S1751731112001383

2. Huxley JN. Impact of lameness and claw lesions in cows on health and production. Livestock Science. 2013;156(1):64-70. DOI: 10.1016/j.livsci.2013.06.012

3. Murray RD, Downham DY, Clarkson MJ, Faull WB, Hughes JW, Manson FJ, Merritt JB, Russell WB, Sutherst JE, Ward WR. Epidemiology of lameness in dairy cattle: description and analysis of foot lesions. Vet Rec. 1996;138(24):586-591. DOI: 10.1136/vr.138.24.586

4. Bell NJ, Bell MJ, Knowles TG, Whay HR, Main DJ, Webster AJ. The development, implementation and testing of a lameness control programme based on HACCP principles and designed for heifers on dairy farms. Vet J. 2009;180(2):178-188. DOI: 10.1016/j.tvj1.2008.05.02

5. Charfeddine N, Pérez-Cabal MA. Claw health data recording in Spanish dairy cattle. ICAR, Berlin, Germany. 2015.

6. Leach KA, Whay HR, Maggs CM, Barker ZE, Paul ES, Bell AK, Main DC. Working towards a reduction in cattle lameness: 1. Understanding barriers to lameness control on dairy farms. Res Vet Sci. 2010;89(2):311-317. DOI: $10.1016 /$ i.rvsc. 2010.02.014

7. van der Waaij EH, Holzhauer M, Ellen E, Kamphuis C, de Jong G. Genetic Parameters for Claw Disorders in Dutch Dairy Cattle and Correlations with Conformation Traits. J Dairy Sci. 2005; 88(10):3672-3678. DOI: 10.3168/jds.S0022-0302(05)73053-8

8. Charfeddine N, Perez-Cabal MA. Effect of claw disorders on milk production, fertility, and longevity, and their economic impact in Spanish Holstein cows. J Dairy Sci. 2017;100(1):653-665. DOI: 10.3168/jds.2016-11434

9. Refaai W, Van Aert M, Abd El-Aal AM, Behery AE, Opsomer G. Infectious diseases causing lameness in cattle with a main emphasis on digital dermatitis (Mortellaro disease). Livestock Science. 2013;156(1):53-63. DOI: 10.1016/j.livsci.2013.06.004

10. van der Linde C, de Jong G, Koenen EP, Eding H. Claw health index for Dutch dairy cattle based on claw trimming and conformation data. J Dairy Sci. 2010;93(10):4883-4891. DOI: 10.3168/jds.2010-3183
11. Refaai W, Gad M, Mahmmod Y. Association of claw disorders with subclinical intramammary infections in Egyptian dairy cows. Vet World. 2017;10(3):358-362. DOI: 10.14202/vetworld.2017.358-362

12. Cook NB, Nordlund KV. The influence of the environment on dairy cow behavior, claw health and herd lameness dynamics. Vet J. 2009;179(3):360-369. DOI: 10.1016/j.tvj1.2007.09.016

13. Cramer G, Lissemore KD, Guard CL, Leslie KE, Kelton DF. The association between foot lesions and culling risk in Ontario Holstein cows. J Dairy Sci. 2009;92(6):2572-2579. DOI: 10.3168/jds.20081532

14. Buch LH, Sorensen AC, Lassen J, Berg P, Eriksson J, Jakobsen JH, Sørensen MK. Hygiene-related and feed-related hoof diseases show different patterns of genetic correlations to clinical mastitis and female fertility. J Dairy Sci. 2011;94(3):1540-1551. DOI: 10.3168/jds.20103137

15. Fjeldaas T, Sogstad AM, Osteras O. Locomotion and claw disorders in Norwegian dairy cows housed in freestalls with slatted concrete, solid concrete, or solid rubber flooring in the alleys. J Dairy Sci. 2011;94(3):1243-1255. DOI: 10.3168/jds.2010-3173

16. Cook NB, Nordlund KV, Oetzel GR. Environmental Influences on Claw Horn Lesions Associated with Laminitis and Subacute Ruminal Acidosis in Dairy Cows. J Dairy Sci. 2004;87:E36-E46. DOI: 10.3168/jds.S0022-0302(04)70059-4

17. Fregonesi JA, Leaver JD. Behaviour, performance and health indicators of welfare for dairy cows housed in strawyard or cubicle systems. Livestock Production Science. 2001;68(2):205-216. DOI: 10.1016/S0301-6226(00)00234-7

18. Sprecher DJ, Hostetler DE, Kaneene JB. A lameness scoring system that uses posture and gait to predict dairy cattle reproductive performance. Theriogenology. 1997;47(6):1179-1187. DOI: 10.1016/S0093-691X(97)00098-8

19. Barkema HW, von Keyserlingk MA, Kastelic JP, Lam T, Luby C, Roy J-P, LeBlanc SJ, Keefe GP, Kelton DF. Invited review: Changes in the dairy industry affecting dairy cattle health and welfare. J Dairy Sci. 2015;98(11):7426-7445. DOI: 10.3168/jds.2015-9377

20. Weaver AD, Atkinson O, St.Jean G, Steiner A. Bovine Surgery and Lameness, 3rd edition. Wiley Blackwell, Oxford, United Kingdom. 2018. 408 pp.

21. de Vries M, Bokkers EAM, van Reenen CG, Engel B, van Schaik G, Dijkstra T, de Boer IJM. Housing and management factors associated with indicators of dairy cattle welfare. Prev VetMed. 2015;118(1):8092. DOI: 10.1016/j.prevetmed.2014.11.016

22. Hernandez-Mendo O, von Keyserlingk MAG, Veira DM, Weary DM. Effects of Pasture on Lameness in Dairy Cows. J Dairy Sci. 2007;90(3):1209-1214. DOI: 10.3168/jds.S0022-0302(07)71608-9

23. Laven RA, Holmes CW. A review of the potential impact of increased use of housing on the health and welfare of dairy cattle in New Zealand. N Z Vet J. 2008;56(4):151-157. DOI: 10.1080/00480169.2008.36827

24. Barker ZE, Amory JR, Wright JL, Mason SA, Blowey RW, Green LE. Risk factors for increased rates of sole ulcers, white line disease, and digital dermatitis in dairy cattle from twenty-seven farms in England and Wales. J Dairy Sci. 2009;92(5):1971-1978. DOI: 10.3168/jds.2008-1590

25. Mülling Ch, Budras KD. Influence of environmental factors on horn quality of the bovine hoof. In Lischer CJ Ed, Proc 10th Int Sympo on Lameness in Ruminants. 1998:214-215.

26. Hedges J, Blowey RW, Packington AJ, O’Callaghan CJ, Green LE. A Longitudinal Field Trial of the Effect of Biotin on Lameness in Dairy Cows. J Dairy Sci. 2001;84(9):1969-1975. DOI: 10.3168/jds.S00220302(01) 74639-5

27. Manske T, Hultgren J, Bergsten C. Prevalence and interrelationships of hoof lesions and lameness in Swedish dairy cows. Prev Vet Med. 2002;54(3):247-263. DOI: 10.1016/S0167-5877(02)00018-1

28. Argáez-Rodríguez FJ, Hird DW, Hernández de Anda J, Read DH, Rodríguez-Lainz A. Papillomatous digital dermatitis on a commercial dairy farm in Mexicali, Mexico: incidence and effect on reproduction and milk production. Prev Vet Med. 1997;32(3-4):275-286. DOI: 10.1016/s0167-5877(97)00031-7 
29. Read DH, Walker RL. Papillomatous digital dermatitis (footwarts) in California dairy cattle: clinical and gross pathologic findings. J Vet Diag Invest : official publication of the American Association of Veterinary Laboratory Diagnosticians, Inc. 1998;10(1):67-76. DOI: $10.1177 / 104063879801000112$

30. Holzhauer M, Brummelman B, Frankena K, Lam TJ. A longitudinal study into the effect of grazing on claw disorders in female calves and young dairy cows. Vet J. 2012;193(3):633-638. DOI: 10.1016/j.tvjl.2012.06.044

31. Gomaa M, El-Azzazy AI, El-Seddawy F, Abdel-Maboud M, Behery A, Abd El-Aal A. Investigating the Relationship between Claw Disorders and Milk Yield before and after Claw Trimming Using Modified Dutch Method in Three Egyptian Dairy Farms. J Anim Health Prod. 2014;2(3):40-45.

DOI: 10.14737/journal.jahp/2014/2.3.40.45

32. Hernandez J, Shearer JK, Webb DW. Effect of lameness on the calving-to-conception interval in dairy cows. J Am Vet Med Assoc. 2001;218(10):1611-1614. DOI: 10.2460/javma.2001.218.1611

33. Amory JR, Barker ZE, Wright JL, Mason SA, Blowey RW, Green LE. Associations between sole ulcer, white line disease and digital dermatitis and the milk yield of 1824 dairy cows on 30 dairy cow farms in England and Wales from February 2003-November 2004. Prev Vet Med. 2008;83(3-4):381-391. DOI: 10.1016/j.prevetmed.2007.09.007

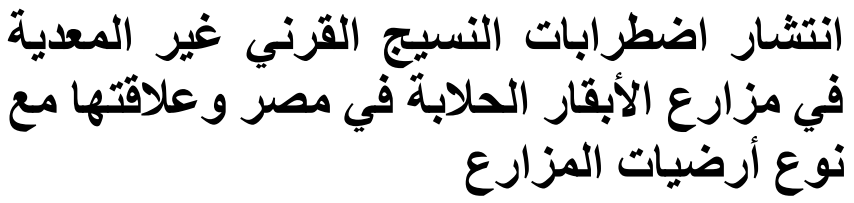

وليد رفاعي'، محمد جمعه'، عبدالباسط محمد عبدالعال'، أحمد السيد

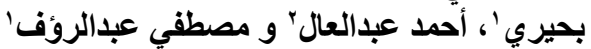

'قسم الجراحة والتخدير والأشعة، بقسم أمراض الباطنة، كلية الطب

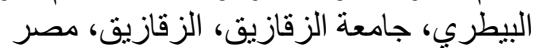

الخلاصة

يعتبر العرج من أكثر الإصابات انتشار ا وأكثر ها من حيث التكلفة

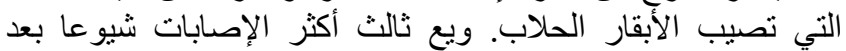

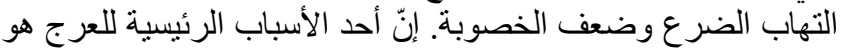

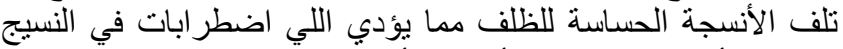

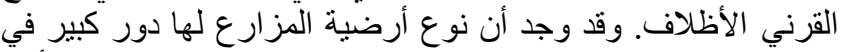

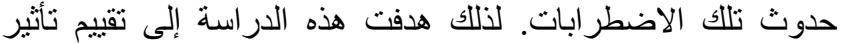

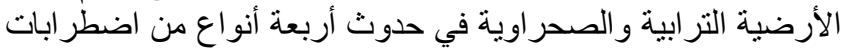

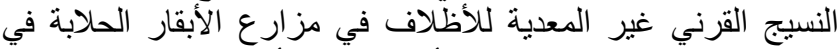
مصر. وقد تضمنت هذه الدراسة أربع مزار ارع ألبان بمحافظتي الثرقية

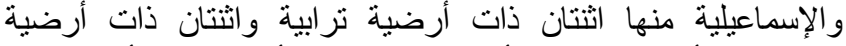

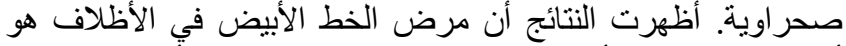

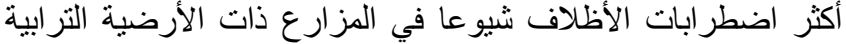

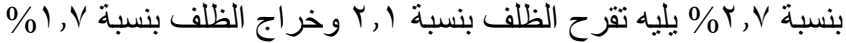

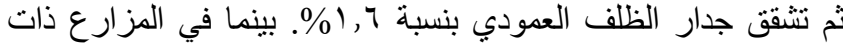
الأرضية الصحراوية كانت نسبة تشقق جدار الظلف العمودي وخراج الظلف ^, •\% ثم مرض الخط الأبيض في الأظلاف بنسبة ؟), •\%

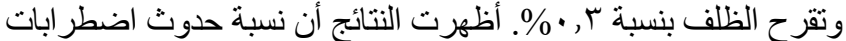

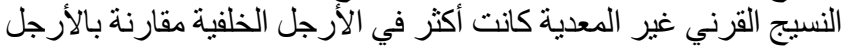

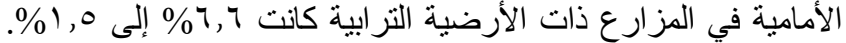

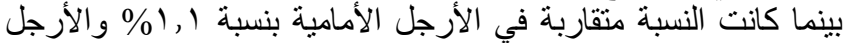
الخلفية بنسبة r, 1\% في بالمزارع ذات الأ الأرضية الصحر اوية. نستتنج

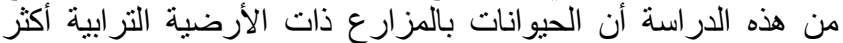

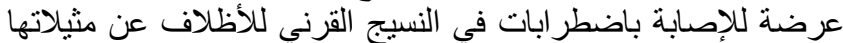
بالمز ارع ذات الأرضية الصحر لاوضية. 